\title{
Study the Relationship Between LULC, LST, NDVI, NDWI and NDBI in Greater Arba Minch Area, Rift Valley, Ethiopia
}

\author{
Muralitharan Jothimani ${ }^{1, *}$, Jagadeshan Gunalan², Radhakrishnan Duraisamy ${ }^{3}$, Abel
}

\author{
Abebe $^{4}$ \\ 1, 2, ${ }^{4}$ Department of Geology, Arba Minch University, Ethiopia \\ ${ }^{3}$ Faculty of Water Resources and Irrigation Engineering, Arba Minch University, Ethiopia \\ *Corresponding author: muralitharangeo@gmail.com
}

\begin{abstract}
The present study aimed to extract the LST and analyses its relationship with land-use/land cover and normalized difference vegetation index (NDVI), normalized difference water index (NDWI), and normalized difference built-up index (NDBI) in the greater Arba Minch, Rift valley, Ethiopia. The study was conducted for the two periods (08 Dec 2013 and 27 Dec 2020 ). The LST results show that $8^{\circ} \mathrm{C}, 7^{\circ} \mathrm{C}$, and $38^{\circ} \mathrm{C}, 34^{\circ} \mathrm{C}$ are low and high during 2013 and 2020. A supervised image classification method was carried out in ArcGIS software to map the different LULC units in the present study area. Overall, the LULC dynamics indicate a notable increment in shrubland \& plantation and, settlement and barren land. And, the forest and water bodies have decreased in small amounts, and bushland has reduced considerably. The current study's NDVI results indicate a notable decrease in the forest area and NDWI values, indicating shrinkage of water bodies during 2020. There are significant positive changes in NDBI value from 2013 to 2020.
\end{abstract}

Keywords: Arba Minch, Ethiopia, LST, LULC, NDBI, NDVI, NDWI.

\section{INTRODUCTION}

In the last few decades, human activities change and modify the environment. For example, modification of land use/land cover (LULC) involves deforestation, encroachment in water bodies, haphazard urbanization, etc. [1], [2]. In Ethiopia, LULC changes are increasing every year, and it is causing significant environmental problems. It is mainly due to population growth, overgrazing, and other factors, such as local communities' insights towards land management, which leads to a massive amount of converting of environment and depletion of natural resources [3]. Remote sensing data provide synoptic views of the spectral, spatial, and temporal changes of the LULC [4], [5], [6], [7].

The LST has been broadly used throughout the world by various researchers to understand yearly fluctuations in temperature and precipitation, the pattern of vegetation, and urban area aggregation [8], [9], [10], [11], [12], [13] were studied LULC changes and its relationship with LST. Thereby, evaluating LST and its changes over a specified period can adequately represent LULC changes in the specific region.

The remote sensing indices such as normalized difference built-up index (NDBI), normalized difference vegetation index (NDVI), and normalized difference water index (NDWI) help extract vegetation, water bodies, and built-up area, respectively [14], [15]. For the past few decades, NDVI has often been used to assess vegetation percentage in the region [16]. The NDVI ranges from -1 to 1 ; high NDVI values indicate that the thick vegetative area and low NDVI values suggest the non-vegetative area [17], [18]. The NDBI values range from -1 to 1 ; high NDBI values indicate that the built-up areas and low NDBI values show the other regions. The NDBI values range from -1 to +1 , higher NDBI values indicating the built-up area, and negative values showing the non-built-up area. By providing timely and synoptic views of land-based coverage, remote sensing images more suitable for monitor NDVI, NDWI, and NDBI [19], [20], [21], [22].

Furthermore, LST has connections with NDVI, NDWI, and NDBI, and it varies significantly in different LULC 
types and times [23], [24], [25], [26], [27], [28] [29], [30], [31], [32]. There are various methods for measuring the LST by using field measurements, but that's very complex and expensive. The recent developments in remote sensing technology provide for high temporal resolution LST assessment. However, the LST measurements and assessments were only carried out in urban centres or a country or a region [33], [34], [35], [36], [37].

\section{RELATED WORKS}

Dynamics of LULC and LST study was carried out in Kathmandu Valley, Nepal [38]. The research was carried out to study the characteristics and processes of a decade and a half of urbanization in India's National Capital Region (NCR), focusing on the relationship between urbanizing land use land cover (LULC) and environmental changes [39]. The following researchers have analyzed relationships between land use, green cover, and surface temperatures using geospatial tools [40, 41, 42, 43]. Over 28 years, a study was carried out to examine the impact of anthropogenic activities and LULC on climate in Bambasi Wereda, Ethiopia [44]. A study was conducted to evaluate the relationship between Normalized Difference Vegetation Index (NDVI) and forage biomass in Teltele rangelands in Ethiopia [45]. LULC changes and their link to land degradation has been studied in the Arsi Negele district, Central Rift Valley, Ethiopia [46]. NDVI dynamics has been studied around Gondar town, Northern Ethiopia [47]

Because of all these and the significance of remote sensing in LST analysis and its relationship with LU/LC changes and remote sensing indices, a study was carried out in the greater Arba Minch area, Rift Valley, Ethiopia. This study aimed to investigate LST variation over a wide range of land use/land coverage classes and the relations among the remote sensing indexes, including NDVI, NDWI, and NDBI. Greater Arba Minch, Rift Valley, Ethiopia, is a present study area situated in a highly undulating topography with a wide variety of land-use/land cover, such as lakes, built-up and barren lands, forest, bush, and shrubland \& plantation. The first research on LST assessment and its relationship with LULC and NDVI, NDWI, and NDBI utilizes Landsat-8 (OLI + TIRS) imagery for the current study area. The present study results are much helpful in the analysis of environmental changes in the present study area [51-55].

\section{TAXONOMY OF RESEARCH}

Landsat-8 satellite images for 08 Dec 2013 and 27 Dec 2020 were downloaded from the USGS Earth Explorer website. The path is 169 , and the row is 56 . In the present research, Landsat 8 images with 11 bands (band1- ultra blue, band 2-blue, band 3-green, band 4-red, band 5- nearinfrared, band 6-short wave infra-red-1, band 7- short wave infrared-2, band 8-panchromatic, band 9- cirrus, ban 10 \& 11 are thermal bands were used to generate the LULC maps and different remote sensing indices. Fig. 1 shows the methodology flow chart of the present study. The LST of the present study was retrieved using RS\& GIS plugin in QGIS software False-colour composite (FCC) of Landsat-8 satellite imagery was used for land use/ land cover mapping. Supervised image classification has been carried out in ArcGIS software through an image classification tool to map the different LULC units in the present study area. The raster calculator of ArcGIS software was used to calculate remote sensing indices. Finally, a correlation assessment was carried out between dynamics of LULC, LST, NDVI, NDBI and NDWI for the selected study period [56].

\section{STUDY AREA}

The present study area, greater Arba Minch, is located in the Southern Nations, Nationalities, and Peoples' Region of Ethiopia. And the current study area is located in the Rift Valley [57]. The study area latitudes are $5^{0} 44^{\prime} \mathrm{N}$ to $6^{0} 16^{\prime} \mathrm{N}$, and longitudes are $37^{\circ} 2^{\prime \prime}$ to $37^{\circ} 45^{\prime}$. Abaya and Chamo are the major lakes in the present study area. The current study area is $500 \mathrm{~km}$ south of Addis Ababa, Ethiopia's capital. Dolerite, rhyolite, and different basalts such as vesicular, aphanitic, porphyritic, colluvial, and alluvial sediments are the principal rock types in the present study area. The present study area has rugged topography, $1109 \mathrm{~m}, 3544 \mathrm{~m}$, and the current study area's minimum and maximum elevation [58-60]. Fig. 2 shows the current study area location map.

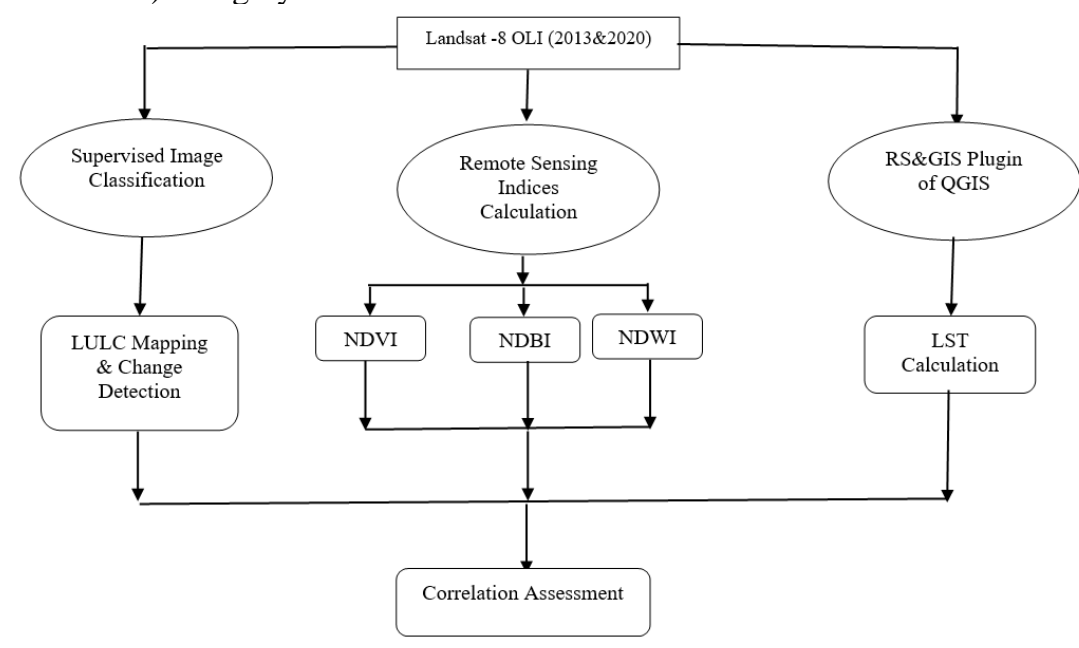

Figure 1 Methodology flow chart 


\section{SCHEMATIC ANALYSIS, RESULTS AND DISCUSSION}

\subsection{LST Retrieval and Analysis}

The LST results show that $8^{\circ} \mathrm{C}, 7^{\circ} \mathrm{C}$, and $38^{\circ} \mathrm{C}, 34^{\circ} \mathrm{C}$ are the low and high LST during 08 Dec 2013 and 27 Dec 2020. Table I represents the statistics of the LST values. The present study's LST results were compared with Earth Skin Temperature (EST) data obtained from NASA (https://power.larc.nasa.gov/data-access-viewer/) [61-63].
For the comparative analysis, fifteen representative points were taken. In the present study, negligible disparities among EST and LST were observed in a few occurrences [64]. It is primarily due to the characteristics of sensors and changes in weather conditions. Fig 3 shows the LST map of the present study area. The LST results showed that areas with water bodies and vegetation have low LST while builtup areas and barren land have high LST (yellow and blue colour, respectively, in Fig. 3)

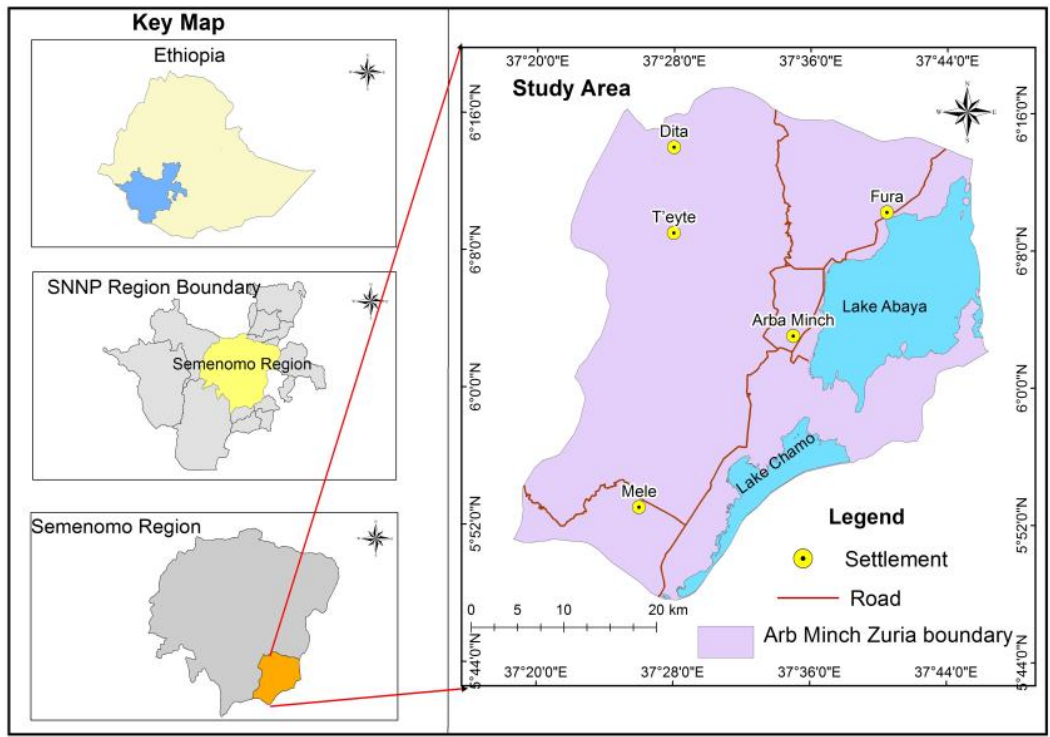

Figure 2 Study Area Map

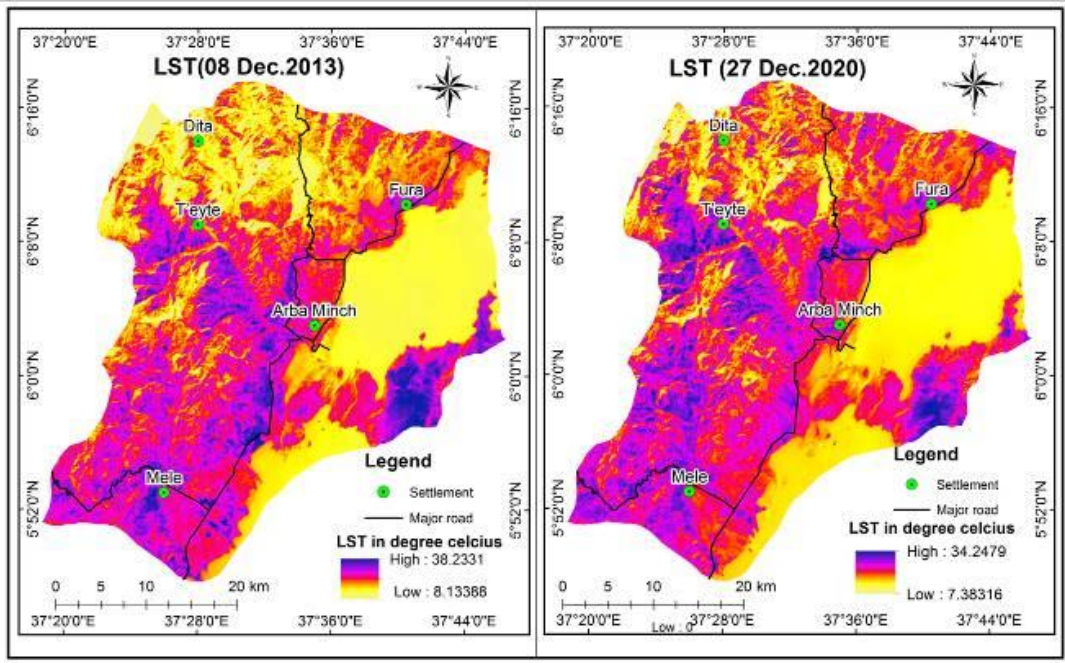

Figure 3 LST Maps

Table 1. Statistics of LST Values

\begin{tabular}{|c|c|c|c|c|c|c|c|c|}
\hline & \multicolumn{4}{|c|}{ 08 Dec.2013 } & \multicolumn{4}{c|}{ 27 Dec.2020 } \\
\cline { 2 - 8 } & Min & Max & Mean & Stdev & Min & Max & Mean & Stdev \\
\hline $\begin{array}{c}\text { LST in Degree } \\
\text { Celsius }\end{array}$ & 8.13 & 38.23 & 24.39 & 3.99 & 7.383 & 34.247 & 22.43 & 3.354 \\
\hline
\end{tabular}




\subsection{LULC Mapping and its Accuracy Assessment}

Six major LULC classes were identified in the current study area viz; (1) bushland, (2) barren land, (3) forest, (4) settlements, (5) shrubland, and plantation (6) water bodies. The LULC mentioned above categories were also confirmed by field checks and high-resolution Google earth's satellite images.

On 08 Dec 2013, the shrubland \& plantation covered most of the study area and enclosed around $25.5 \%$ of the study area. The remaining LULC classes, such as bushland, forests, settlement \& barren land, and water bodies, have covered about $19.14 \%, 19.35 \%, 18.85 \%$, and $17.23 \%$ total area, respectively (Table 2). On 27 Dec 2020, bushland; settlement \& barren land area percentage has increased by $24.38 \%$ and $21.72 \%$, respectively. On the contrary, the forest area, shrubland \& plantation, and water bodies have decreased, and their area percentage is $19.11 \%, 16.89$, and $17.9 \%$, respectively, compared to 08 Dec 2013. Overall, the LULC dynamics indicate a notable increment in shrubland \& settlement and settlement and barren land. The forest and water bodies have decreased in small amounts, and bushland has reduced considerably (Table 2). Fig 4 shows the study period LULC maps.

LULC classification's precision was defined in terms of both the user's exactness and the producer's precision. The producer's precision is described as the quantity of an adequately classified land category on the classification image. On the contrary, the user's accuracy is defined as the likelihood of a class on the classification image being correct when used on the ground. Fifty points were selected randomly from the classified LULC map to carry out the accuracy assessment using Google earth's image archives

Table 2. LULC Distribution and its Changes and field verification. Tables $3 \& 4$ show the accuracy assessment on 08 Dec 2013 and 27 Dec 2020, respectively. The accuracy assessments were carried out using the following equations 1 to 4 .

User Accuracy $=($ Number of correctly classified pixels in each category / Total number of classified pixels in that category) $* 100$

Producer Accuracy $=($ Number of correctly classified pixels in each category / Total number of reference pixels in that category) $* 100$

Overall Accuracy $=($ Total number of classified pixels $/$ Total number of reference pixels) $* 100$

Kappa coefficient $=\left((\right.$ TS $*$ TCS $)-\sum($ Column total $\mathrm{X}$ Row total) / TS2- $\sum($ Column total * Row total $\left.)\right) * 100$

$\mathrm{TS}=$ Total sample and TCS $=$ Total corrected sample

The average user, producer, overall accuracies, and Kappa coefficients are 81\%, 83\%, 83\%, 86\%, 80\%, 78\%, $71 \%$, and $71 \%$ on 08 Dec 2013 and 27 Dec 2020, respectively (Table 3 and 4 ).

\subsection{LULC Dynamics and LST Relationship Analysis}

The LST variation over the different LULC verities may be due to the LST of LULC type. In the present study on 08 Dec, 2013 and 28 Dec 2020, the barren land and settlement area shows the highest LST range $27^{\circ} \mathrm{C}-38^{\circ} \mathrm{C}$ and $24^{\circ} \mathrm{C}-$ $34^{\circ} \mathrm{C}$, respectively. The medium-range LST $\left(22^{\circ} \mathrm{C}-26^{\circ} \mathrm{C}\right.$, 08 Dec 2013 and $20^{\circ} \mathrm{C}-230 \mathrm{C}$, on and 28 Dec 2020) were observed in shrubland \& plantation and bushland. In contrast, on 08 Dec 2013 and 28 Dec 2020, the water bodies and forest area show the lowest LST range $8{ }^{\circ} \mathrm{C}-22^{\circ} \mathrm{C}$ and $7^{0} \mathrm{C}-19^{\circ} \mathrm{C}$, respectively (Fig 3 and 4 ).

\begin{tabular}{|l|l|l|l|l|l|l|}
\hline \multirow{2}{*}{ LULC Types } & \multicolumn{3}{|c|}{ 08 Dec 2013 } & \multicolumn{2}{c|}{ 27 Dec 2020 } & \multicolumn{2}{c|}{$\begin{array}{c}\text { LULC change } \\
\text { 2013 2020 }\end{array}$} \\
\cline { 2 - 8 } & Area Sqkm & Area \% & Area Sqkm & Area \% & Area Sqkm & Area \% \\
\hline Bush land & 333.8 & 19.14 & 425.26 & 24.38 & -91.46 & -27.40 \\
\hline Forest & 337.44 & 19.35 & 333.24 & 19.11 & -4.2 & -1.24 \\
\hline Shrubland \& plantation & 444.67 & 25.5 & 294.5 & 16.89 & 150.17 & 33.77 \\
\hline Settlement \& Barren land & 328.71 & 18.85 & 378.76 & 21.72 & 50.05 & 15.23 \\
\hline Water bodies & 299.36 & 17.23 & 312.22 & 17.9 & -12.86 & -4.30 \\
\hline
\end{tabular}




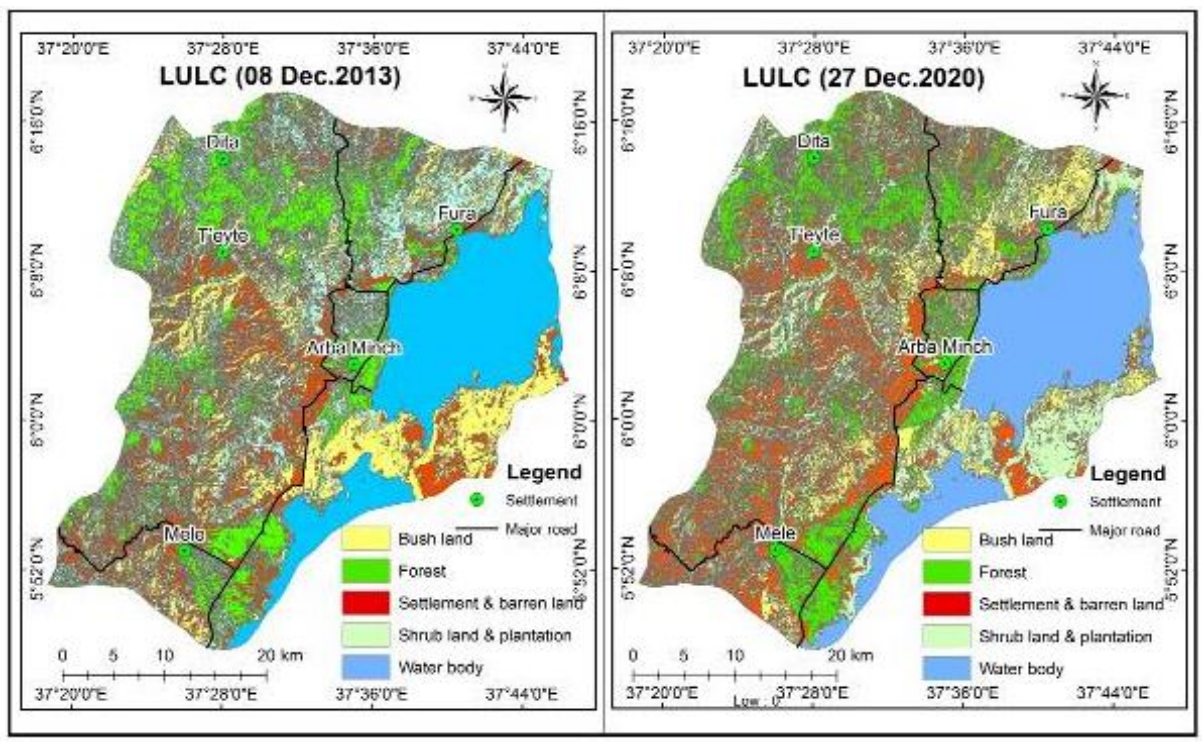

Figure 4 LULC Maps

Table 3. Accuracy Assessment for LULC Classification on 08 DEC 2013

\begin{tabular}{|l|c|c|c|c|c|c|c|}
\hline LULC Types & $\begin{array}{c}\text { Bush } \\
\text { land }\end{array}$ & Forest & $\begin{array}{c}\text { Shrubland \& } \\
\text { plantation }\end{array}$ & $\begin{array}{c}\text { Settlement \& } \\
\text { Barren land }\end{array}$ & $\begin{array}{c}\text { Water } \\
\text { bodies }\end{array}$ & $\begin{array}{c}\text { Total } \\
\text { user) }\end{array}$ & $\begin{array}{c}\text { User's } \\
\text { accuracy }\end{array}$ \\
\hline Bushland & 9 & 1 & 0 & 1 & 0 & 11 & $82 \%$ \\
\hline Forest & 2 & 8 & 0 & 2 & 0 & 12 & $67 \%$ \\
\hline $\begin{array}{l}\text { Shrubland } \\
\text { plantation }\end{array}$ & 1 & 1 & 9 & 0 & 0 & 11 & $82 \%$ \\
\hline $\begin{array}{l}\text { Settlement \& Barren } \\
\text { land }\end{array}$ & 1 & 2 & 0 & 11 & 0 & 14 & $76 \%$ \\
\hline Water bodies & 0 & 0 & 0 & 0 & 2 & 2 & $100 \%$ \\
\hline Total (producer) & 13 & 12 & 9 & 14 & 2 & 50 & \\
\hline Producer's accuracy & $69 \%$ & $67 \%$ & $100 \%$ & $79 \%$ & $100 \%$ & & \\
\hline \multicolumn{7}{|l|}{ Overall accuracy=80\% } \\
\hline
\end{tabular}

Table 4. Accuracy Assessment for LULC Classification on 27 DEC 2020

\begin{tabular}{|l|c|c|c|c|c|c|c|}
\hline LULC Types & Bushland & Forest & $\begin{array}{c}\text { Shrubland } \\
\text { \& } \\
\text { plantation }\end{array}$ & $\begin{array}{c}\text { Settlement } \\
\text { \& Barren } \\
\text { land }\end{array}$ & $\begin{array}{c}\text { Water } \\
\text { bodies }\end{array}$ & $\begin{array}{c}\text { Total } \\
\text { (user) }\end{array}$ & $\begin{array}{c}\text { User's } \\
\text { accuracy }\end{array}$ \\
\hline Bushland & 8 & 2 & 0 & 1 & 0 & 11 & $73 \%$ \\
\hline Forest & 2 & 9 & 0 & 1 & 0 & 12 & $82 \%$ \\
\hline $\begin{array}{l}\text { Shrubland } \\
\text { plantation }\end{array}$ & 1 & 1 & 8 & 1 & 0 & 71 \\
\hline $\begin{array}{l}\text { Settlement \& Barren } \\
\text { land }\end{array}$ & 1 & 1 & 0 & 12 & 0 & 14 & $86 \%$ \\
\hline Water bodies & 0 & 0 & 0 & 0 & 2 & 2 & $100 \%$ \\
\hline Total (producer) & 12 & 13 & 8 & 15 & 2 & 50 & \\
\hline Producer's accuracy & $67 \%$ & $82 \%$ & $100 \%$ & $80 \%$ & $100 \%$ & \\
\hline \multicolumn{7}{|l|}{ Overall accuracy=78\% } \\
\hline
\end{tabular}

\subsection{Remote sensing indices and their relationship with $L S T$}

The following remote sensing indices (NDVI, NDWI, and NDBI) were used in this study, and the same was extracted from the various bands of LANDSAT 8 (OLI \& TIRS) satellite image using the standard formula. The nearinfrared and red bands of the LANDSAT 8 image were used in the present study to calculate NDVI using the following equation in ArcGIS.

NDVI $=($ near-infrared - red $) /($ near-infrared + red $)$

The values' of NDVI vary from -1 to +1 . Higher NDVI values indicate the rich and healthier vegetative cover. The resultant minimum and maximum NDVI values ranged from -0.517 to 0.853 and -0.527 to 0.833 on 08 Dec 2013 and 27 Dec 2020. In NDVI, it was noted which frequent variation 
occurs with time changes due to the change in land use/land cover in the present study area. NDVI has shown its highest positive value on 08 Dec 2013. Fig 5 shows the NDVI map of the present study. The current study's NDVI results indicate a notable decrease in the forest area on 27 Dec 2020. Extensive studies were carried out to find an actual link between LST and NDVI [48], [49], [50]. The study results revealed that high vegetative areas show low LST and vice versa during the study period (Fig 3 and 5).

NDBI and NDWI were considered for perceiving the built-up and water index, respectively. NDBI was calculated using the following equation

NDBI $=($ mid-infrared - near-infrared $) /($ mid-infrared + near-infrared)

The values' of NDBI vary from -1 to +1 . Higher NDBI values indicate the rich and healthier vegetative cover. The resultant minimum and maximum NDBI values ranged from -0.411 to 0.237 and -0.449 to 0.252 on 08 Dec 2013 and 27 Dec 2020. There are notable changes in NDBI value during the study period. The built-up and barren rock areal coverage have increased on 27 Dec 2020 compared to 08 Dec 2013. It has a positive relationship with LST, and it shows high LST values in the settlement and barren land area. Fig 6 shows the NDBI map of the present study. The study results revealed that barren land and settlement show high LST, and the other regions such as forest, water bodies, bushland, and shrubland \& plantation show comparatively low LST (Fig 3 and 6).

NDWI has been used to classify water bodies, and the water index has also been extracted by using given equations.

NDWI = (green - near-infrared $) /($ green + near-infrared $)(7)$

NDWI was calculated in the present study to extract the water bodies of the current study area. There are minor changes in NDWI value during the study period. The resultant minimum and maximum NDWI values ranged from -0.760 to 0.568 and -0.743 to 0.521 on 08 Dec 2013 and 27 Dec 2020. The study results show a decrement in positive NDWI values on 27 Dec 2020, indicating water bodies' shrinkage due to various reasons. NDWI has a negative relationship with LST (Fig 3 and 7). Table 4 shows the statistics of the NDVI, NDWI, and NDBI.

Table 5. NDVI, NDBI, and NDWI Statistics

\begin{tabular}{|c|c|c|c|c|c|c|c|c|}
\hline \multirow{2}{*}{$\begin{array}{l}\text { Remote } \\
\begin{array}{l}\text { Sensing } \\
\text { Indices }\end{array}\end{array}$} & \multicolumn{4}{|c|}{ 08 Dec 2013 } & \multicolumn{4}{c|}{ 27 Dec 2020 } \\
\cline { 2 - 9 } & Min & Max & Mean & Stdev & Min & Max & Mean & Stdev \\
\hline NDVI & -0.517 & 0.853 & 0.374 & 0.387 & -0.527 & 0.833 & 0.327 & 0.393 \\
\hline NDBI & -0.475 & 0.221 & -0.144 & 0.070 & -0.449 & 0.252 & -0.118 & 0.067 \\
\hline NDWI & -0.760 & 0.568 & -0.346 & 0.337 & -0.743 & 0.21 & -0.313 & 0.353 \\
\hline
\end{tabular}



Figure 5 NDVI Maps 


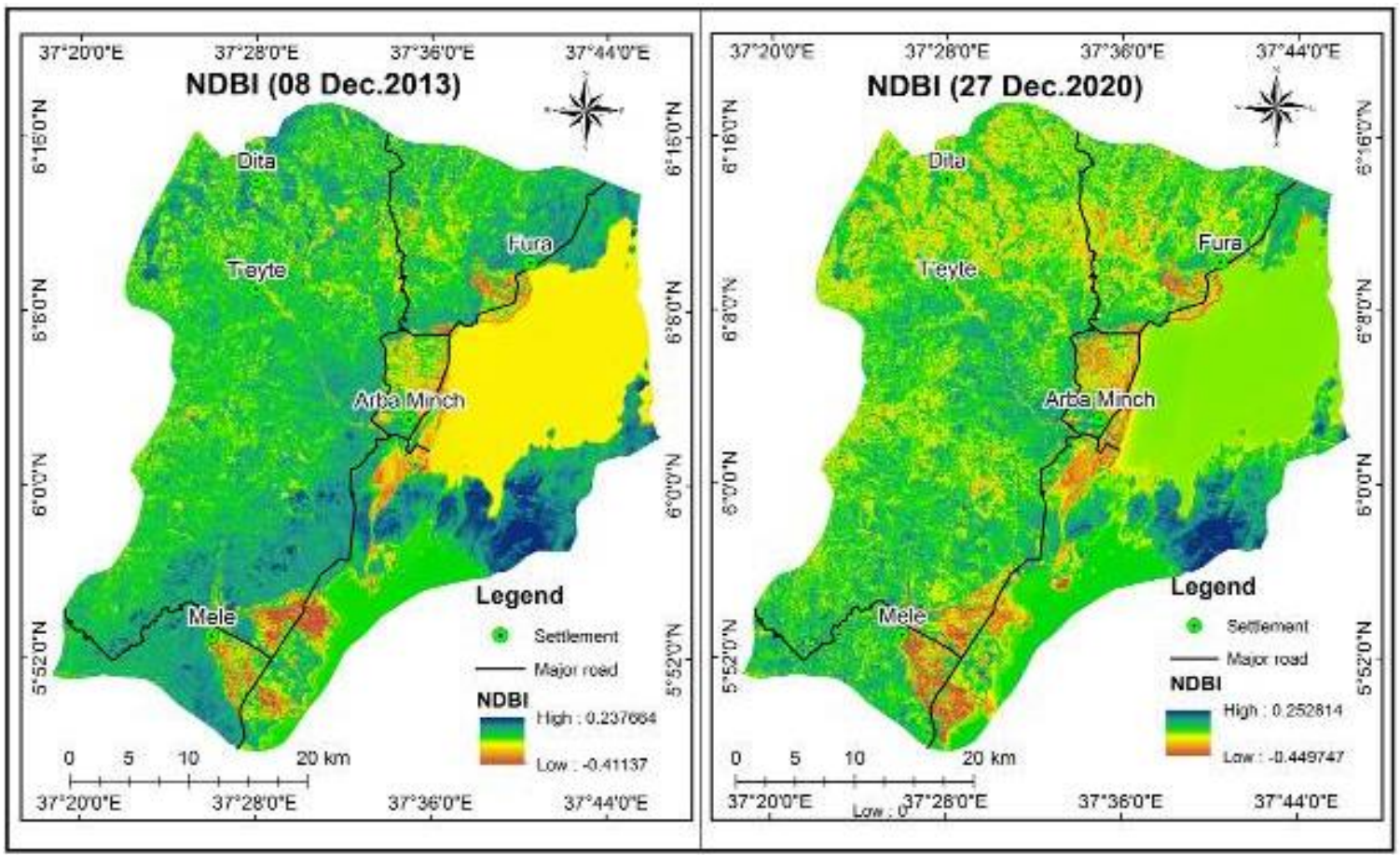

Figure 6 NDBI Maps

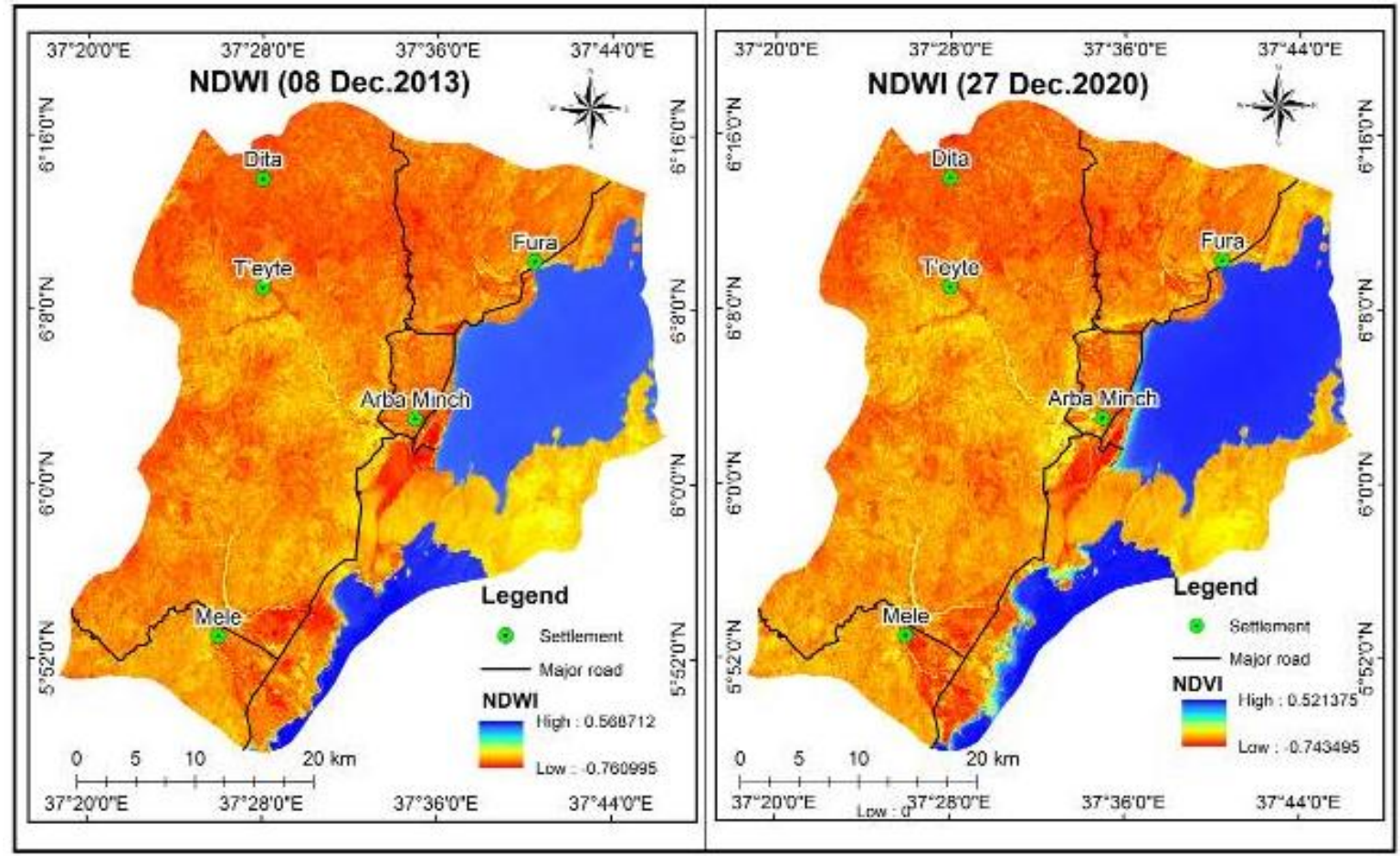

\section{Figure 7 NDWI Maps}

\section{CONCLUSIONS}

In the present study, spatial-temporal trends of LULC, NDVI, NDBI, NDWI, and LST and their interrelationship have systematically analyzed using Landsat- 8 remote sensing data in the greater Arba Minch, Rift Valley, Ethiopia on 08 Dec 2013 and 27Dec 2020. The present study LULC dynamics indicate a notable increment in shrubland \& settlement and settlement and barren land. In contrast, the forest and water bodies have decreased in small amounts, and bushland has reduced considerably. The present study demonstrates the relationship between the LULC, NDVI, NDBI, NDWI, and LST. Results show a positive connection with barren land \& settlement, high NDBI values with the LST. In Contrast LST shows a negative association with water bodies, forests, shrubland and high NDVI and NDWI values. It has proved successful in using RS \& GIS techniques in LULC dynamics, derivation of different remote sensing indices, and further study of their interrelationships. The present study has provided a crucial justification for constant monitoring research of land 
management changes and policy support developing policies to manage land efficiently resources.

\section{REFERENCES}

[1] H. Briassoulis, "Land use change: theoretical and modeling approaches" In S Loveridge (Ed), Web book of regional science. Regional Research Institute, West Virginia University, 2000.

[2] G. Guo, Z. Wu, R. Xiao, Y. Chen, X. Liu, and X. Zhang, "Impacts of urban biophysical composition on land surface temperature in urban heat island clusters", Landscape and Urban Planning, 2015, 135, pp. 1-10. https :// doi.org/10.1016/j.landu rbpla n.2014.11.007.

[3] H. Hurni, K. Tato, and G. Zeleke, "The Implications of Changes in Population, Land Use, and Land Management for Surface Runoff in the Upper Nile Basin Area of Ethiopia". Mountain Research and Development, 2005,25(2), pp, 147-154. doi: 10.1659/0276-4741(2005)025[0147:tiocip]2.0.co;2.

[4] MA. Friedl, D. Sulla-Menashe, B. Tan, A. Schneider, N. Ramankutty, A. Sibley, and X.Huang, "MODIS Collection 5 global land cover: algorithm refinements and characterization of new datasets", Remote Sens Environ,2010,114,pp,168-182.

https://doi.org/10.1016/j.rse.2009.08. 016.

[5] K. Solaimani, M. Arekhi, R. Tamartash, and M. Miryaghobzadeh, "Land use/cover change detection based on remote sensing data (a case study; Neka Basin)", Agric Biol J North Am, 2010, 1(6), pp, 1148 1157.https://doi.org/10.5251/abjna.2010.1.6.1148.1157.

[6] L. Jia, H. Shang, G. Hu, and M.Menenti "Phenological response of vegetation to upstream river flow in the Heihe River Basin by time series analysis of MODIS data", Hydrol Earth Syst Sci, 2011, 15(3), pp,10471064. https://doi.org/10.5194/hess-15-1047-2011.

[7] G. Aredehey, A. Mezgebu , and A. Girma, "Land-use land-cover classification analysis of Giba catchment using hyper temporal MODIS NDVI satellite images", Int J Remote Sens, 2018, 39(3), pp, 810-821.

[8] K. Yu, L. Tan, S. Mumtaz, S. Al-Rubaye, A. AlDulaimi, A. K. Bashir, F. A. Khan, "Securing Critical Infrastructures: Deep Learning-based Threat Detection in the IIoT", IEEE Communications Magazine, 2021.

[9] K. Yu, Z. Guo, Y. Shen, W. Wang, J. C. Lin, T. Sato, "Secure Artificial Intelligence of Things for Implicit Group Recommendations", IEEE Internet of Things Journal, 2021, doi: 10.1109/JIOT.2021.3079574.

[10] H. Li, K. Yu, B. Liu, C. Feng, Z. Qin and G. Srivastava, "An Efficient Ciphertext-Policy Weighted Attribute-Based Encryption for the Internet of Health
Things," IEEE Journal of Biomedical and Health Informatics, 2021, doi: 10.1109/JBHI.2021.3075995.

[11] X. Zhou, and Y. Wang," Dynamics of Land Surface Temperature in Response to Land-Use/Cover Change", Geographical Research, 2010, 49(1), pp, 23-36. doi: $10.1111 / \mathrm{j} .1745-5871.2010 .00686 . x$

[12] A. Owojori, and X. Hongjie ," Landsat image-based lulc changes of san antonio, texas using advanced atmospheric correction and object oriented image analysis approaches", Remote sensing image processing and analysis, 2015, (ES 6973).

[13] S. Mahato, and S. Pal, "Influence of land surface parameters on the spatio-seasonal land surface temperature regime in rural West Bengal, India", Advances In Space Research, 2019, 63(1), pp, 172-189, doi: 10.1016/j.asr.2018.09.014.

[14] D. Dissanayake," Land Use Change and Its Impacts on Land Surface Temperature in Galle City, Sri Lanka" Climate, 2020, 8(5), pp, 65. doi: 10.3390/cli8050065

[15] M. Forkel, N. Carvalhais, J. Verbesselt, MD. Mahecha, CS. Neigh and M. Reichstein, "Trend change detection in NDVI time series: effects of inter-annual variability and methodology". Remote Sens, 2013, 5, pp, 21132144,. https://doi.org/10.3390/rs5052113

[16] K. Yu, M. Arifuzzaman, Z. Wen, D. Zhang and T. Sato, "A Key Management Scheme for Secure Communications of Information Centric Advanced Metering Infrastructure in Smart Grid," IEEE Transactions on Instrumentation and Measurement, vol. 64, no. 8, pp. 2072-2085, August 2015.https://ieeexplore.ieee.org/document/7138617

[17] K. Yu, L. Tan, X. Shang, J. Huang, G. Srivastava and P. Chatterjee, "Efficient and Privacy-Preserving Medical Research Support Platform Against COVID19: A Blockchain-Based Approach", IEEE Consumer Electronics Magazine, doi: 10.1109/MCE.2020.3035520.

[18] Z. Guo, Y. Shen, A. K. Bashir, M. Imran, N. Kumar, D. Zhang and K. Yu, "Robust Spammer Detection Using Collaborative Neural Network in Internet of Thing Applications", IEEE Internet of Things Journal, vol. 8, no. 12, pp. 9549-9558, 15 June15, 2021, doi: 10.1109/JIOT.2020.3003802.

[19] B. Guindon, Y. Zhang, and C. Dillabaugh, "Landsat urban mapping based on a combined spectral-spatial methodology". Remote Sens Environ, 2014, 92, PP, 218-232, 2014.

[20] Kumar, M. Keerthi, B. D. Parameshachari, S. Prabu, and Silvia liberata Ullo. "Comparative Analysis to Identify Efficient Technique for Interfacing BCI System." In IOP Conference Series: Materials Science 
and Engineering, vol. 925, no. 1, p. 012062. IOP Publishing, 2020

[21] Puttamadappa, C., and B. D. Parameshachari. "Demand side management of small scale loads in a smart grid using glow-worm swarm optimization technique." Microprocessors and Microsystems 71 (2019): 102886.

[22] Parameshachari, B. D., H. T. Panduranga, and Silvia liberata Ullo. "Analysis and computation of encryption technique to enhance security of medical images." In IOP Conference Series: Materials Science and Engineering, vol. 925, no. 1, p. 012028. IOP Publishing, 2020.

[23] Y. Julien, JA. Sobrino, C. Mattar, AB. Ruescas, JC. Jimenez-Munoz, G. Soria, V. Hidalgo, M. Atitar, B. Franch, J. Cuenca, Temporal analysis of normalized difference vegetation index (NDVI) and land surface temperature (LST) parameters to detect changes in the Iberian land cover between 1981 and 2001. Int. J. Rem. Sens, 2011, 32 (7).

[24] NT. Son, CF. Chen, CR. Chen, LY. Chang, and VQ. Minh, "Monitoring agricultural drought in the Lower Mekong Basin using MODIS NDVI and land surface temperature data". Int. J. Appl. Earth Obs, 2019, 18 (1).

[25] Y. Chi, H. Shi, X. Wang, and A.Feng," The spatialtemporal characteristics and impact factors of land surface temperature on Five Southern Islands of Miaodao Archipelago, Shandong, China", Chin. J. Ecol, 2015. 34 (8).

[26] Arun, M., E. Baraneetharan, A. Kanchana, and S. Prabu. "Detection and monitoring of the asymptotic COVID-19 patients using IoT devices and sensors." International Journal of Pervasive Computing and Communications (2020).

[27] Kumar, M. Keerthi, B. D. Parameshachari, S. Prabu, and Silvia liberata Ullo. "Comparative Analysis to Identify Efficient Technique for Interfacing BCI System." In IOP Conference Series: Materials Science and Engineering, vol. 925, no. 1, p. 012062. IOP Publishing, 2020.

[28] AH. Tania, MY. Gazi, and MB. Mia, "Evaluation of water quantity-quality, floodplain landuse, and land surface temperature (LST) of Turag River in Bangladesh: an integrated approach of geospatial, field, and laboratory analyses". SN Appl. Sci, 2021, 3, 63. https://doi.org/10.1007/s42452-020-04011-3

[29] S. Ghosh, ND. Chatterjee, and S. Dinda, "Relation between urban biophysical composition and dynamics of land surface temperature in the Kolkata metropolitan area: a GIS and statistical based analysis for sustainable planning". Model. Earth Syst. Environ. 2019, 5, 307329. https://doi.org/10.1007/s40808-018-0535-9
[30] S. Rahaman, S. Jahangir, MS. Haque, "Spatio-temporal changes of green spaces and their impact on urban environment of Mumbai, India". Environ Dev Sustain, 2021, 23, 6481-6501. https://doi.org/10.1007/s10668020-00882-z

[31] T. Akter, MY. Gazi, MB. Mia, "Assessment of Land Cover Dynamics, Land Surface Temperature, and Heat Island Growth in Northwestern Bangladesh Using Satellite Imagery". Environ. Process.2021, 8, 661-690. https://doi.org/10.1007/s40710-020-00491-y

[32] CS. Chanu, L. Elango, and GR. Shankar, "A geospatial approach for assessing the relation between changing land use/land cover and environmental parameters including land surface temperature of Chennai metropolitan city, India". Arab J Geosci, 2021, 14, 132. https://doi.org/10.1007/s12517-020-06409-0

[33] TA. Abera, J. Heiskanen, P. Pellikka, M. Rautiainen, and EE. Maeda, "Clarifying the role of radiative mechanisms in the spatio-temporal changes of land surface temperature across the horn of Africa". Remote Sens. Environ, 2019, 221.

[34] C. Wang, Y. Li, SW.Myint, Q. Zhao, and EA. Wentz, "Impacts of spatial clustering of urban land cover on land surface temperature across K€oppen climate zones in the contiguous United States". Landsc. Urban Plann. 2019, 192.

[35] Nguyen, Tu N., Bing-Hong Liu, Nam P. Nguyen, and Jung-Te Chou. "Cyber security of smart grid: attacks and defenses." In ICC 2020-2020 IEEE International Conference on Communications (ICC), pp. 1-6. IEEE, 2020.

[36] Pham, Dung V., Giang L. Nguyen, Tu N. Nguyen, Canh V. Pham, and Anh V. Nguyen. "Multi-topic misinformation blocking with budget constraint on online social networks." IEEE Access 8 (2020): 7887978889.

[37] Naeem, Muhammad Ali, Tu N. Nguyen, Rashid Ali, Korhan Cengiz, Yahui Meng, and Tahir Khurshaid. "Hybrid Cache Management in IoT-based Named Data Networking." IEEE Internet of Things Journal (2021).

[38] O. Sarif, R. Bhagawat, E. Nigel, and A. Stork, "Assessment of Changes in Land Use/Land Cover and Land Surface Temperatures and Their Impact on Surface Urban Heat Island Phenomena in the Kathmandu Valley (1988-2018)" ISPRS International Journal of Geo-Information, 2020， 9,12, 726. https://doi.org/10.3390/ijgi9120726

[39] S. Richa, and P.K. Joshi, "Mapping environmental impacts of rapid urbanization in the National Capital Region of India using remote sensing inputs", Urban Climate, 2016, 15, 70-82, ISSN 2212-0955, https://doi.org/10.1016/j.uclim.2016.01.004. 
[40] I. Sandholt, K. Rasmussen, and J. Anderson, "A simple interpretation of the surface temperature/vegetation index space for assessment of surface moisture status". Remote Sensing Environ. 2002, 79, 213-224.

[41] J. A Voogt, and T.R. Oke, "Thermal remote sensing of urban climates. Remote Sensing Environ". 2003, 86, 370-384.

[42] Q. Weng, D. Lu, and J. Schubring, "Estimation of land surface temperature-vegetation abundance relationship for urban heat island studies". Remote Sensing Environ. 2004, 89, 467-483.

[43] H. Xiao, and Q. Weng, The impact of land use and land cover changes on land surface temperature in a karst area of China. J. Environ. Manage. 2007, 85, 245- 257.

[44] T. Emiru, H. R. Naqvi, and M.A. Athick, "Anthropogenic impact on land use land cover: influence on weather and vegetation in Bambasi Wereda, Ethiopia". Spat. Inf. Res. 2018, 26, 427-436. https://doi.org/10.1007/s41324-018-0186-y

[45] Y. Fenetahun, W. Yong-dong, and Y. You, "Dynamics of forage and land cover changes in Teltele district of Borana rangelands, southern Ethiopia: using geospatial and field survey data". BMC Ecol. 2020, 20, 55. https://doi.org/10.1186/s12898-020-00320-8

[46] M. Zenebe, T. B. Habitamu, W. Teshale, and A. Zebene, K. Habtemariam, "Land use and land cover changes and the link to land degradation in Arsi Negele district, Central Rift Valley, Ethiopia", Remote Sensing Applications: Society and Environment, 2018. 12, 1-9, ISSN2352-9385,

https://doi.org/10.1016/j.rsase.2018.07.012

[47] N. Agam, WP. Kustas, and MC. Anderson, "A vegetation index-based technique for spatial harpening of thermal imagery" Remote Sens Environ, 2017 107, pp, 545-558. https ://doi.org/10.1016/j.rse.2006.10.006

[48] J. Muralitharan, and M. Wuletaw. "Trend analysis of Normalized Difference Vegetation Index using Landsat Satellite data: Study in-and-around Gondar town, North West Ethiopia". Journal of Control \& Instrumentation. 2019, 10, 3, 25-33.

[49] AK. Inamdar, A. French, and S. Hook, "Land surface temperature retrieval at high spatial and temporal resolutions over the southwestern United States". J Geophys Res Atmos, 2008, 113, pp, 1-18, https ://doi.org/10.1029/2007J D0090 48

[50] W. Li, JDM. Saphores, and TW. Gillespie, "A comparison of the economic benefits of urban green spaces estimated with NDVI and with high-resolution land cover data". Landsc Urban Plan, 2015, 133, pp, 105-117.
[51] Y. Zhang, and L. Sun, "Spatial-temporal impacts of urban land use land cover on land surface temperature: case studies of two Canadian urban areas". Int. J. Appl. Earth Obs, 2019, 75

[52] C. Alexander, "Normalized difference spectral indices and urban land cover as indicators of land surface temperature (LST)". Int. J. Appl. Earth Obs, 2020, 86.

[53] J. Song, W. Chen, J. Zhang, K. Huang, B. Hou, and AV. Prishchepov, "Effects of building density on land surface temperature in China: spatial patterns and determinants". Landsc. Urban Plann. 2020, 198.

[54] J. Shen, A. Huete, NN. Tran, R. Devadas, X. Ma,D. Eamus, Q.Yu," Diverse sensitivity of winter crops over the growing season to climate and land surface temperature across the rainfed cropland-belt of eastern Australia". Agric. Ecosyst. Environ, 2018, 254.

[55] LS. Ferreira, DHS. Duarte, "Exploring the relationship between urban form, land surface temperature and vegetation indices in a subtropical megacity". Urban Clim, 2019, 27.

[56] H. Xu, "A new index for delineating built-up land features in satellite imagery". Int J Remote Sens, 2008, 29, pp,4269-4276.

[57] B. Bhatta, Analysis of urban growth pattern using remote sensing and GIS: a case study of Kolkata, India. Int J Remote Sens, 2009, 30, pp, 4733-4746.

[58] P. Griffiths, P. Hostert, O. Gruebner, and S. Van Der Linden, "Mapping megacity growth with multi-sensor data". Remote Sens Environ, 2010, 114, pp, 426-439.

[59] D. How Jin Aik, M. Ismail, and F.Muharam, "Land Use/Land Cover Changes and the Relationship with Land Surface Temperature Using Landsat and MODIS Imageries in Cameron Highlands, Malaysia" Land, 2020, 9(10), pp, 372. doi: 10.3390/land9100372

[60] MY. Gazi, MZ. Rahman, and MM. Uddin, "Spatiotemporal dynamic land cover changes and their impacts on the urban thermal environment in the Chittagong metropolitan area, Bangladesh". GeoJournal (2020). https://doi.org/10.1007/s10708-020-10178-4

[61] AT. Kaptué, L. Prihodko, and NP. Hanan, "On regreening and degradation in Sahelian watersheds". Proc Natl Acad Sci U S A, 2015, 112(39), pp, 1213312138. https://doi.org/10.1073/pnas.1509645112

[62] S.Pal, and S. Ziaul, "Detection of land use and land cover change and land surface temperature in English Bazar urban centre". Egypt J Remote Sens Space Sci, 2017, 20(1), pp, 125-145. https://doi.org/10.1016/j. ejrs.2016.11.003 
[63] MTU. Rahman, F. Tabassum, M. Rasheduzzaman, H. Saba, L. Sarkar, J. Ferdous, SZ.Uddin and Z. Islam, "Temporal dynamics of land use/ land cover change and its prediction using CAANN model for southwestern coastal Bangladesh". Environ Monit Assess,2017, 189:565. https://doi.org/10.1007/s10661$\underline{017-6272-0}$

[64] F. Ahmad, "A review of remote sensing data change detection: Comparison of Faisalabad and Multan Districts, Punjab Province, Pakistan". J Geogr Reg Plan, 2012, 5(9), pp, 236-25. https://doi.org/10.5897/ JGRP11.121 